E3S Web of Conferences 1, 04007 (2013)

DOI: $10.1051 / \mathrm{e} 3$ sconf/20130104007

(C) Owned by the authors, published by EDP Sciences, 2013

\title{
Effect of Cadmium in Wood Ash on Spring Wheat Vitality: pot experiment
}

\author{
P. Ochecova ${ }^{1}$, P. Tlustos ${ }^{1}$ and J. Szakova ${ }^{1}$ \\ ${ }^{1}$ Department of Agroenvironmental Chemistry and Plant Nutrition, Czech University of Life Sciences Prague, Prague, \\ CZECH REPUBLIC, ochecova@af.czu.cz
}

\begin{abstract}
The reutilization of residues derived from the bio-energy processes in agriculture is important for more effective nutrient cycle in ecosystem. This study evaluated wood fly ash (WFA) as an agricultural soil supplement. Spring wheat was grown on two different soils amended with different ash rates. The aim of our study was to investigate long-term effects of Cd contained in WFA on spring wheat vitality and yield during 3 years of cumulative ash application. Cd concentration in samples was analysed by inductively coupled plasma optical emission spectrometer (ICP-OES). WFA addition significantly decreased $(p<0.05)$ total Cd content in spring wheat, especially in the second experimental year and with increased WFA rate, probably because of increased soil $\mathrm{pH}$ and ash sorption ability caused by the ash addition. Grain yield was affected by the addition of ash at lower doses where we observed almost $100 \%$ yield increase compared to untreated control and wheat straw showed the highest yields at the most ash enriched treatments growing in the last year. The risk of $\mathrm{Cd}$ contamination appears to be low, even from the long-term view and hence there are justifiable grounds for applying wood ash to the soil.
\end{abstract}

Key words: Cadmium, wood fly ash, spring wheat, pot experiment

\section{Introduction}

Increasing share of renewable energies belongs among the priorities of the European Union and biomass plays a major role in this scenario. Combustion is one of the most common use of biomass and it is necessary to find reuse for increasing amount of by-products, such as biomass ash. Application of ash to agricultural land offers an opportunity for the recovery of essential plant nutrients (Zhang et al., 2002), because this residual material contains chemical elements with considerable fertilizer value (Insam et al., 2009). A limiting factor for the use of wood ash is the presence of heavy metals (Obernberger and Supancic, 2009), and their content depends on the age of plant, growing site, distance from the source of pollution, etc. (Saidur et al., 2011). High concentration of cadmium in fly ash is due to the fact that cadmium sublimates or reacts by forming gaseous compounds during the combustion process. Later on, when the flue gas is cooled, it forms aerosols and agglomerate or condense on fly ash particles and the concentration of cadmium in fly ash can be about 27 times higher than in the bottom ash (Obernberger et al., 1997). Bottom ash is because of its lower cadmium content allowed for agriculture use in some countries as a complex Ca-fertilizer (Ribbing, 2007), but fly ash from wood combustion can consider a threat to the environment (Hansen et al., 2001).

The objective of present work was to investigate the existing threat to the environment when the ash is applied to agriculture soil due to the changes in cadmium content in wheat biomass after wood fly ash addition.

\section{Materials and Methods}

The 3-years pot experiment was set up at the Czech University of Life Sciences Prague in April 2009. Wood fly ash (WFA) was applied into two soils with different physico-chemical properties and different levels of $\mathrm{Cd}$ contamination. The Píšt'any soil (Fluvisol - light soil) was used with regard to its higher risk of element release and the Příbram soil (Cambisol - medium soil) represents the most common soil type in the Czech Republic and also contains higher amounts of heavy metals, especially cadmium and lead.

The experiment was set up in seven treatments, on the Cambisol was evaluated control and annual addition of three ash doses $(10,25$ and $50 \mathrm{~g} / \mathrm{pot})$ and on the Fluvisol control and annual addition of two ash doses (10 and $25 \mathrm{~g} /$ pot). The scheme of experiment is summarized in Table 2. 
Table 1. Level of $\mathrm{pH}, \mathrm{CEC}$ value and total $\mathrm{Cd}$ content of used ash and soils

\begin{tabular}{|l|c|c|c|}
\hline Sample & $\mathbf{p H}$ & $\mathbf{C E C}$ & $\mathbf{C d}$ \\
$\left(\mathrm{CaCl}_{2}\right)$ & $(\mathrm{mval} / \mathrm{kg})$ & $(\mathrm{mg} / \mathrm{kg})$ \\
\hline WFA & 11.5 & 205.3 & 3.09 \\
\hline Fluvisol & 6.5 & 196.8 & 2.60 \\
\hline Cambisol & 5.7 & 165.8 & 4.30 \\
\hline
\end{tabular}

Table 2. Scheme of the pot experiment

\begin{tabular}{|c|c|c|c|}
\hline Treatment & Soil & Ash* & $\mathbf{N}^{*}$ \\
\hline I. & Cambisol & 0 & 0.5 \\
\hline II. & Cambisol & WFA/10 & 0.5 \\
\hline III. & Cambisol & WFA/25 & 0.5 \\
\hline IV. & Cambisol & WFA/50 & 0.5 \\
\hline V. & Fluvisol & 0 & 0.5 \\
\hline VI. & Fluvisol & WFA/10 & 0.5 \\
\hline VII. & Fluvisol & WFA/25 & 0.5 \\
\hline
\end{tabular}

*g/pot

All treatments were fertilized by the uniform dose of nitrogen $\left(0.1 \mathrm{~g} \mathrm{~N}\right.$ in the form of $\mathrm{NH}_{4} \mathrm{NO}_{3}$ per $1 \mathrm{~kg}$ of soil), to the treatments II - IV, VI and VII ash was applied and mixed with soil. Treated soil was filled into the pots $(5 \mathrm{~L})$, sown by 30 seeds of spring wheat (cv. Scirocco) per pot and washed by deionized water. The plants were continuously watered by deionized water during cultivation, treated against pests and diseases, sampled at booting stage and harvested at full maturity. After harvest, the $\mathrm{Cd}$ content was determined in wheat green biomass, straw and grains.

\section{Ash, plant and soil analysis}

For the total Cd content determination was weighed $0.5 \mathrm{~g}$ sample to the Teflon beakers, into which was gradually added $8 \mathrm{ml} \mathrm{HNO}$ (65\%), $3 \mathrm{ml} \mathrm{HCl} \mathrm{(37 \% )} \mathrm{and} 2 \mathrm{ml} \mathrm{HF}$ (40\%). Then the beakers were submitted to microwave digestion (Ethos 1, MLS GmbH). After the microwave digestion the solution was left at $160{ }^{\circ} \mathrm{C}$ to evaporate to dryness. Further was added $5 \mathrm{ml}$ Aqua Regia $(\mathrm{HCl}$ : $\mathrm{HNO}_{3}$ in a ratio $3: 1$ ) and the contents of the beaker was transferred, using deionized water, to $25 \mathrm{ml}$ tubes. Thus prepared sample was then measured.

Concentration of $\mathrm{Cd}$ was determined by inductively coupled plasma optical emission spectrometer ICP-OES (Varian Vista Pro, Varian, Australia).

\section{Statistical analysis}

The effects of wood ash application on yield and $\mathrm{Cd}$ concentration in spring wheat were examined by analyses of variance. When this test revealed significant differences, the mean values were compared by Tukey's means test. Differences were considered significant at $p<0.05$ for all parameters.

\section{Results and Discussion}

The results indicated that the total $\mathrm{Cd}$ content in all parts of spring wheat significantly decreased with increasing ash rates which could be caused by increasing $\mathrm{pH}$ value and thus limiting Cd mobility. Dimitriou et al. (2006) noted similar conclusions, namely reduction in solubility of $\mathrm{Cd}$ in treatments where ash was applied. These reductions followed the changes in $\mathrm{pH}$ soil values. Between treatments III and IV were not found any statistical differences (Figure 1). Treatments on Fluvisol reached significantly lower amounts of $\mathrm{Cd}$ than on Cambisol which is caused by lower Cd values in used soil. During 3 years of cultivation there was observed decrease of $\mathrm{Cd}$ content in green biomass and straw in the second year and in the third year compare to the first one, mean Cd content in grain was not affected by ash application (Figure 2). Hansen et al. (2001) provide a possible explanation of hard bounds of $\mathrm{Cd}$ in fly ash from wood, $\mathrm{Cd}$ is most probably present as oxide together with calcium or as $\mathrm{CdSiO}_{3}$ and therefore could be $\mathrm{Cd}$ less available in the subsequent experimental years. Grain $\mathrm{Cd}$ content was the lowest and stable throughout the years (0.42-0.44 mg/kg).

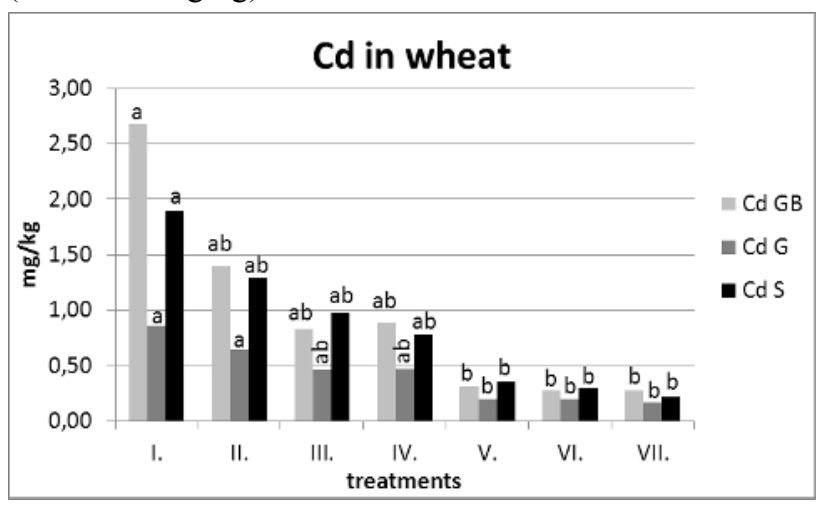

$\mathrm{GB}$ - green biomass $\mathrm{G}$ - grain $\mathrm{S}$ - straw

Fig. 1. Total mean $\mathrm{Cd}$ content in spring wheat $(\mathrm{mg} / \mathrm{kg})$ at individual treatments

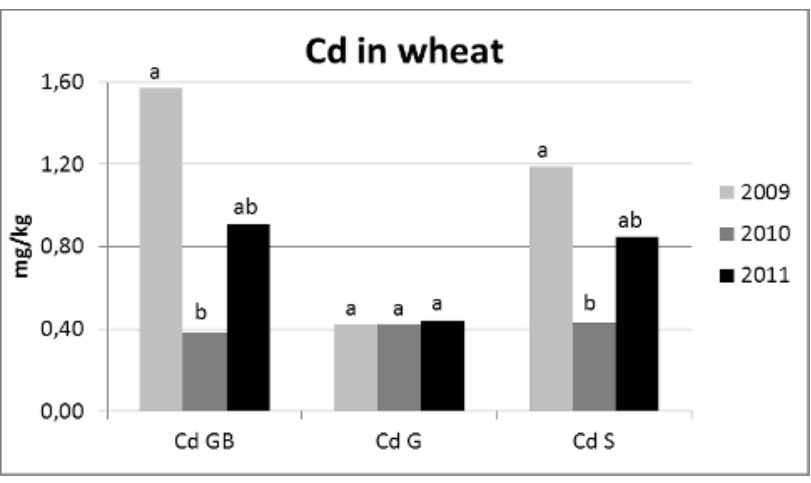

GB - green biomass $\mathrm{G}$ - grain $\mathrm{S}$ - straw

Fig. 2. Total $\mathrm{Cd}$ content in spring wheat $(\mathrm{mg} / \mathrm{kg})$ in individual years 
Grain yield was affected by the addition of ash (Figure 3) especially in first year at lower rates where we observed increase of almost $100 \%$ compared to untreated control and this is in accordance with results of Uckert et al. (2001) who states that on the poor sandy soil the ash fertilizer treatments influenced the yield of oat significantly. The grain yield in the $2 \mathrm{t} \mathrm{ha}^{-1}$ ash treatment

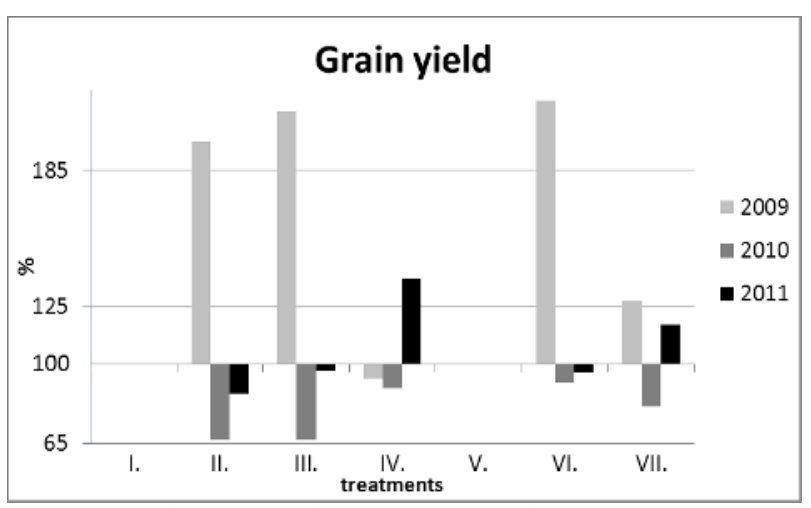

was more than twice higher than at the untreated control. Wheat straw showed the highest yields at the most ash enriched treatments in year 2011 .

Fig. 3. Relative grain yield of wheat (\%), control treatments $\mathrm{I}$ and $\mathrm{V}=100 \%$

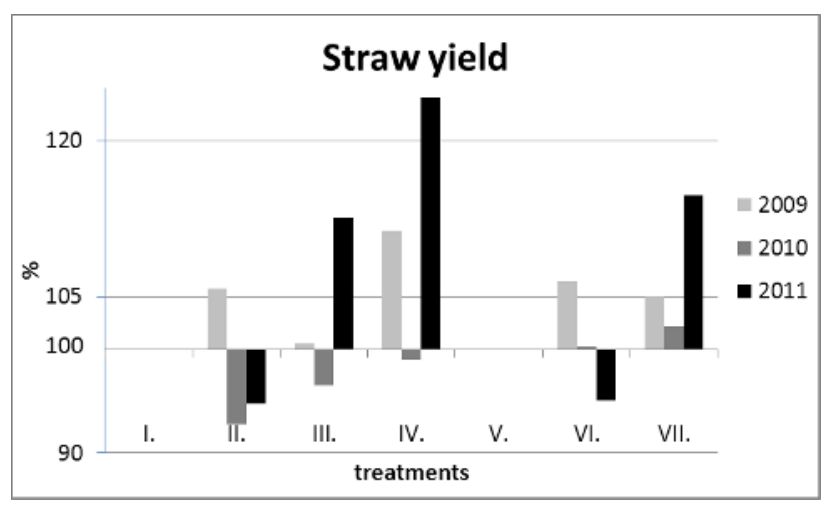

Fig. 4. Relative straw yield of wheat (\%), control treatments $\mathrm{I}$ and $\mathrm{V}=100 \%$

\section{Conclusion}

Pot experiment focused on $\mathrm{Cd}$ content in spring wheat after wood fly ash addition confirmed that ash could be used as a fertilizer material in agriculture and its application does not present any threat for the environment. Ash enrichment causes increase in soil $\mathrm{pH}$, decrease the availability of $\mathrm{Cd}$ and support higher yields without any other nutrient addition except nitrogen. The effect was stronger with the length of experiment.

\section{Acknowledgements}

The research presented has been financially supported by NAZV project No. QI102A207 and CIGA 21140/1313/3107.

\section{References}

Dimitriou I, Eriksson J, Adler A, Aronsson P, Verwijst T. Fate of heavy metals after application of sewage sludge and wood-ash mixtures to short-rotation willow coppice. Environ Pollut 2006; 142:160-169.

Hansen HK, Pedersen AJ, Ottosen LM, Villumsen A. Speciation and mobility of cadmium in straw and wood combustion fly ash. Chemosphere 2001; 45:123-128.

Insam H, Franke-Whittle IH. Knapp BA, Plank R. Use of wood ash and anaerobic sludge for grassland fertilization: Effects on plants and microbes. Die Bodenkultur 2009; 60:43-55.

Obernberger I, Biedermann F, Widmann W, Riedl R. Concentrations of inorganic elements in biomass fuels and recovery in the different ash fractions. Biomass and Bioenergy 1997; 12:211-224.

Obernberger I, Supancic K. Possibilities of ash utilization from biomass combustion plants. Proceedings of the $17^{\text {th }}$ European Biomass Conference and Exhibition. Hamburg. ETA-Renewable Energies (Ed.). Italy. 2009.

Ribbing C. Environmentally friendly use of non-coal ashes in Sweden. Waste Manage 2007; 27: 1428-1435.

Saidur R, Abdelaziz EA, Demirbas A, Hossain MS, Mekhilef S. A review on biomass as a fuel for boilers. Renewable and Sustainable Energy Reviews 2011; 15:2262-2289.

Uckert G, Mette R, Sattelmacher B. Utilisation of boiler ash from biomass heating plants as fertilizer subsitut. Horst WJ et al. (Eds.), Plant nutrition-Food security and sustainability of agro-ecosystems 2001, 992-993.

Zhang FS, Yamasaki S, Nanzyo M. Waste ashes for use in agricultural production: I. Liming effect: contents of plant nutrients and chemical characteristics of some metals. Sci Total Environ 2002; 284:215-225. 